\title{
Verkostojohtajan roolit ja kompetenssit kolmannen sektorin johtajien näkökulmasta
}

\author{
Kirsi Lehto, Lotta Pitkänen \& Jari Autioniemi
}

\begin{abstract}
Network Leader Roles and Competencies: A Third-Sector Perspective

This article studies the competencies and skills that are seen important for a network leader in order to achieve trustworthy collaboration, using collaborative leadership theory as a theoretical base. We follow a framework by Agranoff and McGuire (2001), who grouped network management behaviors in collaboration into four categories: activation, framing, mobilization, and synthesizing. The network leaders have distinctive roles in different phases of collaboration: a visionary motivator, a community builder, a strategic stimulator, and a fair mediator. The qualitative data was collected through a survey of network leaders in Finnish social and healthcare nonprofit organizations.
\end{abstract}

Keywords: network, collaboration, leadership, competencies, third sector

\section{JOHDANTO}

Tämän tutkimuksen tarkoituksena on kartoittaa kolmannen sektorin johtajien näkökulmasta verkostojohtajan kompetensseja ja rooleja, jotka näkyvät verkostojohtajan käyttäytymisessä yhteistyön eri vaiheissa. Näkökulmamme on organisaatioiden välisessä verkostoyhteistyössä ja yhteistyöhön perustuvassa johtajuudessa (collaborative leadership). Käsite collaborative leadership suomennetaan muun muassa yhteisölliseksi johtajuudeksi (Jäppinen 2012), yhteistyöhön eli kollaboraatioon pyrkiväksi verkoston johtamiseksi (Niiranen 2017, 136) tai yhteistyöhön perustuvaksi johtajuudeksi (Parkkinen ym. 2017, 23). Verkostojohtajalla tarkoitamme tässä artikkelissa verkostoissa toimivaa ja yhteistyötä edis- tävää johtajaa (collaborative leader, collaborator, network leader). Etsimme vastausta kysymykseen: mitä rooleja ja kompetensseja kolmannen sektorin johtajat pitävät arvossaan verkostomaisessa yhteistyössä ja kollaboraatiossa?

Hallinta ja organisaatioiden välinen verkostomainen toiminta haastavat johtajuuden verkostoissa. Kompleksiset ongelmat vaativat sektoreiden välistä yhteistyötä ja johtajuutta, sillä näitä ongelmia ei voida ratkoa yksin yhden sektorin tai yhden organisaation voimin. Keskusteluissa korostuvat yhä enemmän yhteisöllisyys sekä kansalaisten osallistaminen, julkisen ja yksityisen sektorin yhteistoiminta, verkostomainen toiminta sekä uudenlaiset yhteistyömuodot (Getha-Taylor \& Morse 2013, 74-75; Klijn 2008, 506). Hallinta havainnollistuu esimerkiksi julkisen ja kolmannen sektorin välisissä, usein kompleksisissa ja vaikeasti johdettavissa vuorovaikutustilanteissa (Klijn 2008, 506, 508). Näin ollen hallinta on julkishallintoa tai julkista sektoria laajempi ilmiö, eivätkä kollektiiviset päämäärät tai kollaboratiivinen toiminta välttämättä perustu laillisen tai muodollisen auktoriteetin varaan: keskinäisen riippuvuuden kasvu näkyy kansainvälisten, kansallisten ja paikallisten toimijoiden välillä. (Bevir 2013, 1-2; Tiihonen 2008, 21-23.)

Kansallisesti julkisen ja kolmannen sektorin väliset hallintasuhteet näkyvät Sote-uudistuksen valmistelussa. Uudistus edellyttää kuitenkin yhä vahvempaa roolia kolmannen sektorin, kuten myös yksityisen sektorin toimijoilta, ja tavoitteena on, että niiden osuus palveluntuotannossa tulisi kasvamaan (HE 15/2017, 287). Järjestöt toimivat jo nyt tiiviissä yhteistyössä kuntien kanssa. Yhteistyössä on omat erityispiirteensä ja haasteensa. Järjestöjen ensisijaisena tehtävänä ei ole tuottaa palveluja kunnille vaan ajaa omien jäsentensä etuja. Toisaalta kuntien tulisi nähdä järjestötoimijat tasavertaisina kumppaneina kompleksisia ongelmia ratkottaessa. (Ks. esim. Möttönen $2005,100,104$.) 
Mitä tämä vaatii johtajuudelta? Toimintaympäristön kompleksisuus edellyttää ensinnäkin uudenlaisia näkökulmia ja ajatuksia sekä ymmärtää että tutkia johtajuutta kolmannella sektorilla. Toiseksi kolmannen sektorin johtajat toimivat osin erilaisista lähtökohdista käsin kuin esimerkiksi julkisen sektorin johtajat, sillä heillä on usein monia eri sidosryhmiä ml. kansalaiset, ja rahoittajat, joille he ovat vastuussa. (ks. Osula \& Ng 2014, 90-91.) Kolmanneksi, kuten Osula ja $\mathrm{Ng}(2014,91)$ huomauttavat, he tarvitsevat paljon erilaista osaamista, vahvaa luonnetta, etenkin suhteessa arvoihin sekä yhteistyöhön. Lisäksi verkostojen hallinta edellyttää johtajuutta, jossa fokuksessa ovat verkoston yhteisesti jaetut intressit. (Imperial ym. 2016, 126).

Vaikka organisaatioiden välistä yhteistyötä on tutkittu paljon, tuovat Simo ja Bies (2007, 126) esille, että kolmannen sektorin osuus on jäänyt vähäisemälle huomiolle. O'Leary ym. (2012) puolestaan esittävät, että kirjallisuudessa painottuu enemmän verkostojen ja niihin kuuluvien organisaatioiden tarkastelu kuin yksittäiset johtajat ja heidän roolinsa yhteistyön toteuttamisessa. Huxham ja Vangen $(2000,1159)$ huomauttavat, että terminä yhteistyö (collaboration) viittaa ennen muuta organisaatioiden väliseen yhteistyöhön kuin yksilöihin. On kuitenkin muistettava, että vaikka ammattimaiset verkostot muodostuvat niissä toimivista organisaatioista, niin lopulta yhteistyötä tekevät näissä työskentelevät yksilöt (O’Leary ym. 2012, 70). Täten yksilöiden rooli yhteistyössä ja sen onnistumisessa on olennaista. Yhteistyön johtamisen taidot ovat avainasemassa menestyksekkäässä verkostotoiminnassa (O’Brien ym. 2013, 26).

\section{YHTEISTYÖHÖN PERUSTUVA JOHTAJUUS VERKOSTOISSA}

Organisaatioiden välinen yhteistyö eri sektoreiden välillä määritellään Brysonin ja kumppaneiden $(2006,44 ; 2015,648)$ sanoin: "kahden tai useamman sektorin väliseksi tiedon, resurssien, toiminnan ja kykyjen jakamiseksi, jotta saavutetaan tavoitteita, joita yhden sektorin organisaatiot eivät voi yksin saavuttaa". Johtajuus on tärkeässä roolissa organisaatioiden välisessä yhteistyössä, ja se vaikuttaa yhteistyön onnistumiseen (O’Brien ym. 2013, 26; Bryson ym. 2015, 658).
Määritelmä on lähes identtinen Agranoffin $(2006,56)$ esittämän määritelmän kanssa.

Yhteistyöhön perustuva johtajuus eroaa hierarkkisesta johtajuudesta, jossa korostuvat johtajan auktoriteetti ja alaisten motivointi (Morse 2008, 82; Silvia 2011, 70). Verkostoissa eivät vuorostaan päde tavanmukaiset hierarkiamallit eivätkä selkeät johtamisauktoriteetit. Sitä vastoin, yhteistyöhön perustuva johtajuus painottaa jaettua valtaa; Morse $(2008,82)$ korostaa kumppanuutta ja yhteistä oppimista ja nostaa esiin Follettin (1924) ajatuksen vallan jakamisesta; "power-with" ennemmin kuin "power-over". Paitsi vallan jakaminen myös tehtävien ja tunnustuksen jakaminen on tärkeää. Ansell ja Gash (2012, 1,18 ) näkevät, että yhteistyöhön perustuva johtajuus on ennemminkin mahdollistavaa kuin ohjaavaa. Johtajuuden tarkoituksena on luoda olosuhteet, jotka edesauttavat ja helpottavat verkosto-osapuolten vuorovaikutusta. Johtajat rohkaisevat sekä tukevat osapuolia työskentelemään yhdessä tehokkaasti. Samaan tapaan Archer ja Cameron (2013, 18-19) katsovat, että yksi verkostojohtajan tärkeimmistä tehtävistä on luoda ympäristö, jossa kaikki yhteistyötahot voivat saavuttaa yhteisesti asetetut tavoitteet ja tarkoitukset. Tämä voi olla haastavaa etenkin kolmannen sektorin johtajille. Johtajuutta tarvitaan niin ikään, jotta saadaan sovittua säännöt, rakennettua luottamusta verkostotoimijoiden välille, lisättyä vuorovaikutusta ja arvioitua yhteisiä onnistumisia (Ansell \& Gash 2008, 554). Verkostojohtaja toimii siten fasilitaattorina edistäen verkosto-osapuolten ymmärrystä yhteisestä visiosta sekä verkostoitumisen merkityksestä. Verkostojohtajalta vaaditaan yhä enemmän strategisen johtamisen osaamista, kykyä hahmottaa "iso kuva" ja taitoa työskennellä yhdessä, jotta tavoitteet voidaan saavuttaa. (O'Leary 2015, 545.)

Niiranen $(2017,136)$ kuvaa kollaboraatioon, yhteistyöhön pyrkivää verkoston johtamista kaksiulotteiseksi. Tällöin johtamisessa kohdataan kaksi toisilleen vastakkaista vaatimusta. Ensimmäinen niistä liittyy johtamiseen verkoston sisällä, ja toinen verkoston ja sen ympäristön suhteisiin. Verkoston eri osien hajanaisuudesta huolimatta johtamisessa tulisi kyetä luomaan eheyttä ja yhdentymistä verkoston sisällä. Johtamisen tehtävänä on huolehtia verkoston eri osien välisistä vuorovaikutussuhteista, edis- 
tää verkoston sisäistä avoimuutta ja säilyttää erilaiset näkemykset salliva monimuotoisuus. Verkoston ulkopuolella korostuu johtamisen toinen tehtävä, jota Niiranen $(2017,136)$ kuvaa vastakkainasettelun hallinnan paradoksiksi. Tällöin johtamisessa on tärkeää edistää luotettavuutta ja monitasoista yhteistyötä sekä pitää yllä vuorovaikutussuhteita. Verkoston johtamisessa nämä ulkoiset ja sisäiset odotukset ovat usein läsnä samanaikaisesti.

Verkoston ulkopuolelta tulevat odotukset, samoin verkostoon kuuluvien toimijoiden taustaorganisaatiot saattavat kohdistaa verkostotoimintaan keskenään ristiriitaisiakin odotuksia, puhumattakaan itse verkostotoimijoiden erilaisista intresseistä ja tavoitteista. Tällöin verkoston johtamisen tavoitteeksi muodostuu verkoston oman, sisäisen yhteisyyden luominen ja verkostoon kuuluvien jäsenten yhteistyön tukeminen verkoston sisällä. (Niiranen 2016, 306-308.) Myös Puustinen $(2017,116,153)$ näkee verkostojohtamisen kompleksisena ilmiönä. Tällöin verkostojohtaminen muodostuu suhteissa jakautuneena, ei vain yksittäisen johtajan kautta. Hän toteaa, että rakenteellisia ulottuvuuksia voi johtaa, mutta yhteen kietoutumista ei, ja nämä molemmat elementit ovat verkostojen johtamisessa läsnä. Johtajuus verkostoissa ei ole irrallaan ajasta tai paikasta. Siihen myös liittyy ennakoimattomia ja arvaamattomia elementtejä. Verkostoissa johtajuus on siten "manoveröimistä paradoksien keskellä".

\section{JOHTAJAN KOMPETENSSIT JA KÄYTTÄYTYMINEN}

Heikka (2008, 50) määrittelee kompetenssin olevan kontekstisidonnainen ja ajan myötä kehittyvä ominaisuus: se sisältää ne tiedot ja taidot, joita tarvitaan tietyn työtehtävän suorittamisessa. Tutkimuskirjallisuudessa on jossain määrin pyritty tunnistamaan verkostoyhteistyössä tarvittavia kompetensseja (ks. esim. McGuire 2006, 40). Archer ja Cameron $(2013,138)$ näkevät, että etenkin tulevaisuudessa ketteryyden, kärsivällisyyden ja empatian merkitys tulevat kasvamaan. Myös O'Leary $(2015,538)$ tuo empaattisuuden esiin, ja lisää, että verkostojohtaja tarvitsee lisäksi rehellisyyttä, integriteettiä, ystävällisyyttä, huumorintajua sekä nöyryyttä. Macaulay ja
Lawton (2006) korostavat kompetenssin suhdetta hyveellisyyteen: näitä kahta ei voida ajatella toisistaan riippumattomina johtajuuden ominaisuuksina, vaan ne vaikuttavat välttämättä toisiinsa.

Seuraamme tässä tutkimuksessa Agranoffin ja McGuiren jaottelua (2001, 298-299; ks. myös McGuire 2002, 2006, 37; McGuire \& Silvia 2009, 39-40, 53). He ryhmittelevät verkostojohtajan käyttäytymisen neljään eri kategoriaan niiden toiminnallisten erojen perusteella. Kategoriat ovat verkostoyhteistyön käynnistäminen, yhteistyön rakentaminen, mobilisointi sekä yhteistyön syventäminen. Näitä voidaan edelleen pitää hyödyllisinä verkostojohtamisen kuvaajina, mutta samalla McGuire ja Agranoff $(2014,153)$ toteavat, että toisin kuin alkuperäisessä mallissa oletettiin, verkostojohtaminen ei etene lineaarisesti tai vaiheittain kronologisesti. Verkostot mitä ilmeisimmin sisältävät samanaikaisesti toimintoja, jotka ovat sijoitettavissa näihin neljään eri kategoriaan. He myös havaitsivat, että verkostolla voi olla yhden johtajan sijasta useita johtajia, jotka jakavat johtamisvastuita tilanteiden mukaan.

Verkostoyhteistyön käynnistäminen sijoittuu nimensä mukaisesti verkostoyhteistyön alkuvaiheeseen. Käynnistäminen edellyttää potentiaalisten verkosto-osapuolten tunnistamista ja tarvittavien resurssien määrittelyä tavoitteiden saavuttamiseksi. Verkostoyhteistyön käynnistäminen on yhteistyön onnistumisen kannalta olennaista, sillä eri ihmisillä ja organisaatiolla on resursseja kuten asiantuntemusta tai kokemusta, joita muilla organisaatioilla ei ole. Mikäli verkosto ei toimi odotetulla tavalla, johtajalta odotetaan kykyä organisoida verkoston rakenteita uudelleen. (Agranoff \& McGuire 2001, 298299.)

Yhteistyön rakentaminen liittyy johtajan käyttäytymiseen verkoston rakenteita järjesteltäessä ja integroitaessa. Tällöin verkostojohtajan tehtävänä on osallistujien roolien, toiminnan pelisääntöjen, toimintakulttuurin sekä arvojen luomisen edistäminen ja helpottaminen sekä näistä sopiminen. Näin johtajat voivat yrittää vaikuttaa osallistujien rooleihin, jotta he toimisivat verkoston yhteisen tarkoituksen edistämiseksi ja noudattaisivat yhteisiä sääntöjä ja aikatauluja. Johtajat auttavat myös kehittämään verkoston 
rakennetta ja muuttamaan sitä tarpeen mukaan. He kehittävät yhteistä ja jaettua näkemystä verkostosta. Johtajan on oleellista muokata osapuolten ymmärrystä yhteistyön luonteesta kontekstissa, jonka toimintamekanismit poikkeavat perinteisistä auktoriteettiasetelmista. (McGuire 2006, 37; McGuire \& Silvia 2009, 39.)

Verkostoyhteistyössä tarvitaan ajattelutapaa, jossa korostuu avoimuus uusille ideoille ja näkemyksille sekä kyky auttaa muita onnistumaan tehtävissään. Ennen kaikkea se on yhteisen, kollektiivisen edun tavoittelua. Jotta tässä voidaan onnistua, tarvitaan itseluottamusta, kykyä ottaa riskejä sekä intohimoista suhtautumista toiminnan tavoitteiden saavuttamiseen. Verkostojohtajat tarvitsevat lisäksi tunneälyä ja kykyä johtaa itseään. Siihen kuuluu johtajuuden, resurssien ja, kuten edellä mainittiin, vallan jakamista. (O’Leary 2015, 537-538, 545.)

Mobilisoinnissa verkostojohtajan tehtävänä on hankkia tukea verkosto-osapuolilta ja sidosryhmiltä. Tämä tarkoittaa osapuolten motivointia, yhteistyön oikeutuksen varmistamista ja perustelemista sekä yhteiseen tehtävään sitouttamista. (Agranoff \& McGuire 2001, 299-300; McGuire 2006, 37). Tässä mielessä mobilisointi voidaan nähdä jaettuna ja jatkuvana tehtävänä, jotta voidaan varmistaa verkostotoiminnan tehokkuus. Agranoff $(2005,34)$ korostaa tässä kategoriassa erityisesti johtajuuden merkitystä ja verkostojohtajan saamaa taustatukea edustamiltaan organisaatioilta ja omilta esimiehiltään. Verkostojohtaja joutuu tavallaan vakuuttamaan nämä intressiryhmät yhteistyön merkityksestä kompleksisten ongelmien ratkaisussa ja samalla rohkaisemaan nykyisiä sekä potentiaalisia yhteistyötahoja mukaan yhteistyöhön. (Silvia 2011, 69.)

Mobilisointi on tapa saada asiat tehdyiksi. Se tarkoittaa rohkaisevaa ja energisoivaa toimintatapaa, jolla verkoston osapuolia kannustetaan yhteistyöhön. (Huxham \& Vangen 2008, 216.) O'Leary $(2015,538-539,545)$ korostaa ryhmätyöskentelytaitojen merkitystä sekä informaation, vallan, tavoitteiden ja johtajuuden jakamista. Ne, jotka onnistuvat yhteistyössä, kohtelevat muita tasavertaisesti ja reilusti sekä huolehtivat yhteistyökumppaneidensa hyvinvoinnista. Huxham ja Vangen (2008, 220-222) kuitenkin toteavat, että johtajan rooli yhteistoiminnan kannustamisessa on haastava. Etenkin kasvok- kain tapahtuva vuorovaikutus on elintärkeää, ja sitä voidaan edistää kutsumalla ihmisiä koolle erilaisiin työpajoihin, -ryhmiin ja seminaareihin.

Yhteistyön syventäminen tarkoittaa sitä, että johtajan odotetaan luovan edellytykset verkostotoimijoiden tehokkaalle ja tulokselliselle yhteistyölle. Verkoston johtajan on pyrittävä rakentamaan ja ylläpitämään luottamusta osallistujien kesken, jotta verkoston tavoitteet saavutetaan. Tehokas verkostojohtaminen mahdollistaa tuottavan ja palkitsevan yhteistyön eri sidosryhmien välillä. Sen tavoitteena on myös auttaa vähentämään ja poistamaan yhteistyön esteitä. (McGuire 2006, 37; McGuire \& Silvia 2009, 40.)

Getha-Taylor tuo tutkimuksessaan samanlaisia elementtejä julki kuin yllä mainitut Agranoff ja McGuire. Getha-Taylorin (2008) malli esittelee aikaisempien hyvien kokemusten pohjalta johtajuuskompetensseja tehokkaaseen kollaboraatioon. Mallin mukaan kompetenssit perustuvat interpersonaalisen ymmärtämisen, yhteistyön ja johtajuuden ulottuvuuksiin. Interpersonaalisessa ymmärtämisessä korostuvat empatian osoittaminen ja motivaation ymmärtäminen. Yhteistyössä merkitsevät yhteisten saavutusten korostaminen, resurssien reilu jakaminen ja ristiriitojen sovittelu. Johtajuudessa tärkeitä kompetensseja ovat moninaisuuden sovittaminen ja selkeän näkölinjan luominen. Kompetenssien suhteen on olemassa positiivisia ja negatiivisia indikaattoreita. Esimerkiksi interpersonaalista ymmärtämistä vahvistavat toisten näkemysten ja tarpeiden huomioiminen. Tätä vuorostaan heikentää kyvyttömyys ymmärtää asiantuntemuksen ulkopuolelta tulevia näkemyksiä.

Foster-Fishman ja kumppanit (2001) ovat tutkineet kollaboratiivisen yhteistyön kompetensseja: heidän tutkimuksensa perustuu 80 eri tutkimuksen laadulliseen analyysiin. FosterFishmanin ja kumppaneiden mukaan kompetenssit ja kyvyt perustuvat neljään eri ulottuvuuteen, eli yksilölliseen (Member Capacity), suhteisiin perustuvaan, (Relational Capacity) organisationaaliseen (Organizational Capacity) ja ohjelmalliseen kapasiteettiin (Programmatic Capacity). Yksilöllinen kapasiteetti edellyttää kollaboraatiotaitoja, kuten konfliktinratkaisukykyä, tehokasta kommunikointia ja motivaatiota. Suhteisiin perustuva kapasiteetti koskee positiivisen ilmapiirin luomista, yhteisen vision kehittämistä, vallanjakoa, arvojen moninaisuutta ja 


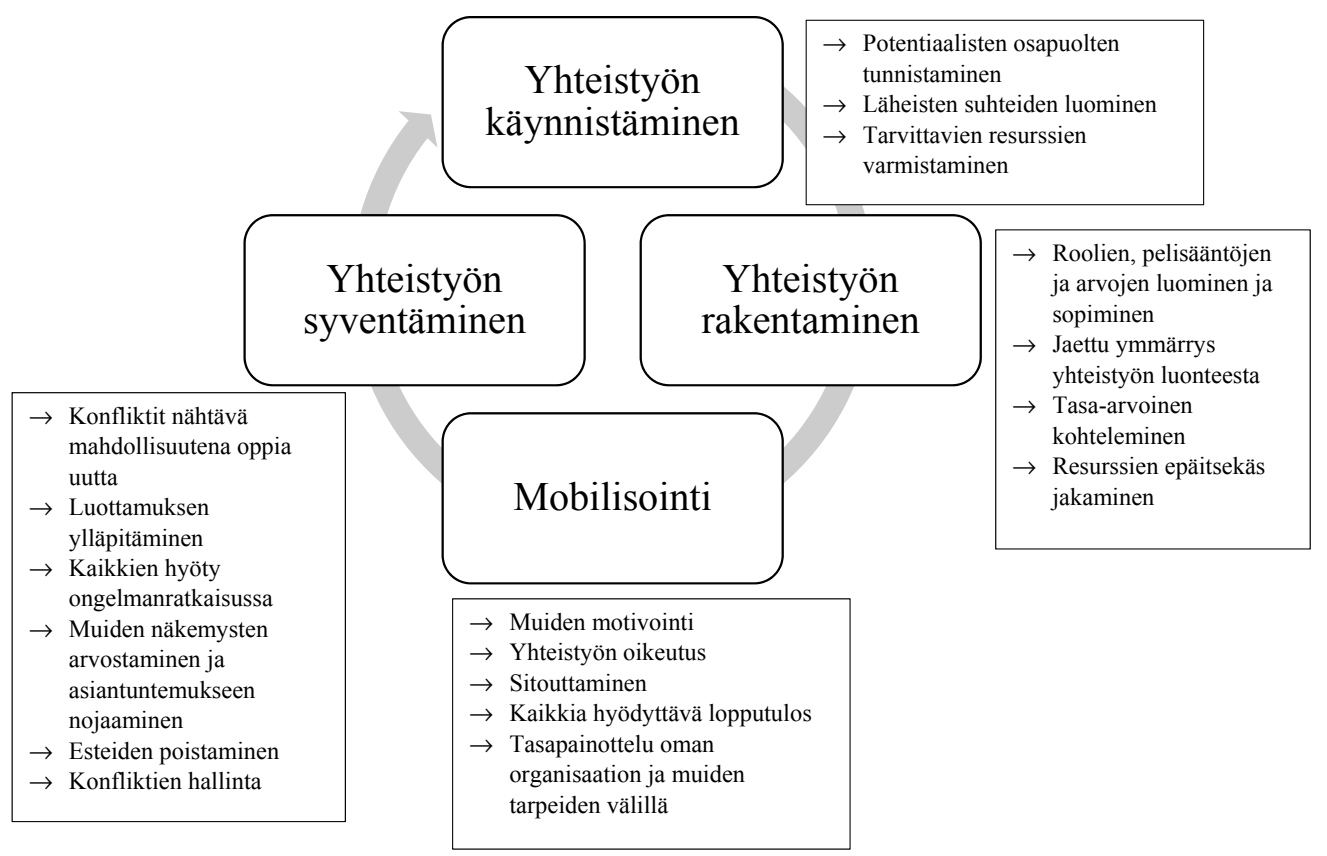

Kuvio 1. Johtajuuskompetenssien tarkastelua kollaboraation eri vaiheissa (Agranoff \& McGuire 2001 mukaillen, ks. myös Getha-Taylor 2008; Foster-Fishman 2001).

positiivisten ulkoisten suhteiden kehittämistä. Organisationaalinen kapasiteetti perustuu tehokkaaseen johtajuuteen ja muodollisiin prosesseihin.

Lopuksi, ohjelmallisella kapasiteetilla tarkoitetaan selkeitä päämääriä ja realistisia tavoitteita. O’Learyn ja kumppaneiden (2012) tutkimus korostaa pitkälti samoja periaatteita: yksilöllisiä piirteitä, vuorovaikutustaitoja, yhteistyötä, strategista johtajuutta ja asiantuntijuutta. Tilivelvollisuuden, kompetenssin ja eettisten standardien tulisi tukea toisiaan, eikä olla ristiriidassa toistensa kanssa (Farazmand 2002).

Kuviossa 1 on koostettu yllä olevien tutkimusten näkemyksiä kompetensseista Agranoffin ja McGuiren (2001) jaottelun pohjalta. Agranoffin ja McGuiren (2001), Getha-Taylorin (2008) ja Foster-Fishmanin (2001) teorioita yhdistävät esimerkiksi näkemykset jaetusta missiosta, reiluista pelisäännöistä ja ristiriitojen sovittelun tärkeydestä. Tästä ei voida kuitenkaan tehdä johtopäätöstä, että kompetenssit noudattelisivat Agranoffin ja McGuiren esittämää vaiheittaista tyypittelyä.
Verkostoyhteistyön osapuolia ei voi verrata tavanomaisiin tiimeihin. On tärkeää huomata, että yhteistyön osapuolilla on erilaisia sitoumuksia ja intressejä. Näin ollen heitä tulisi johtaa ja motivoida näiden mukaisesti. (Archer \& Cameron 2013, 36.) Jännitteet ja ristiriidat ovat toisinaan läsnä yhteistyösuhteissa: kun ihmiset tekevät yhteistyötä, konflikteja ja valtakamppailuja voi esiintyä hyvästä yhteistyöhengestä huolimatta. Tällöin verkostojen johtamiseen kuuluu yhteistyön esteiden poistamista ja minimointia. (McGuire \& Silvia 2015, 305.)

Rakentava konfliktien hallinta on tärkeää, sillä ristiriitaisia näkemyksiä ei aina voida välttää verkostoyhteistyössä (Archer \& Cameron 2013, 10). Tämä pätee konfliktitilanteiden lisäksi resurssien ja vallan jakamiseen - on esimerkiksi vältettävä sanelupolitiikkaa. (Crosby \& Bryson 2010,222 .) On tärkeää, että yhteistyön osapuolet ymmärtävät, kuinka käsitellä monimutkaisia suhteita ja kilpailevia etuja. Muuten yhteistyö ei voi saavuttaa täyttä potentiaaliaan. (O`Brien ym. 2013, 40.) Osapuolten on nähtävä yhteistyön edut ja ymmärrettävä, ettei yhteistyöhön 
käytetty aika ole hukattua aikaa. Yhteistyöllä saavutetut edut eivät olisi mahdollisia, jos osapuolet toimisivat erikseen.

Luottamus on välttämätön osa onnistunutta verkostoitumista ja edellytys menestyksekkäälle ja ylläpitävälle yhteistyölle (McGuire 2006, 38; Huxham \& Vangen 2008, 153, 159). Luottamus tarkoittaa odotusta siitä, että yhteistyön eteen tehdyistä ponnisteluista koituu hyötyä. Se on uskoa kumppaneiden tahtoon ja kykyyn etsiä yhteistyön etua. (Huxham \& Vangen 2008, 154.) "Luottamus on liima, joka pitää verkoston koossa" (Silvia 2011, 70). Luottamuksen rakentaminen on tärkeää, koska verkoston jäsenet edustavat erilaisia toimijoita. Toimijoilla voi olla isoja eroja organisaatiokulttuurissa, menettelytavoissa, näkemyksissä ja tavoitteissa. Kun verkoston osapuolet luottavat toisiinsa, he todennäköisemmin sitoutuvat paremmin kumppanuuteen: näin ollen heidän toimintaansa ohjaa verkoston yhteinen etu (Silvia 2011, 70).

Mitkä tekijät vaikuttavat ihmisten väliseen luottamukseen verkostoissa? Lambrightin ja kumppaneiden (2010, 64, 76-79) mukaan verkosto-osapuolten menestyksekäs yhteistyö ja rakenteiden samankaltaisuudet vaikuttavat luotettaviin suhteisiin sekä yhteistyön säännöllisyyteen. On selvää, että osapuolten kokemalla luottamuksella on myönteinen vaikutus odotettuun yhteistyöhön tulevaisuudessa. Avain pitkään suhteeseen on siinä, kuinka luottamusta voidaan rakentaa ja vaalia (Huxham \& Vangen 2008, 159).

Tuloksellisen yhteistyön edellytyksiä ovat ymmärrys yhteistoiminnan tarkoituksesta, organisaatio- ja sektorirajat ylittävä toiminta, yhteistyön esteiden voittaminen, toimiva ja tarkoituksenmukainen vuorovaikutus sekä tarvittavan tuen saaminen. (McGuire \& Silvia 2015, 310.) Yhteistyön johtaminen edellyttää kuuntelemista, selkeää kommunikointia ja ryhmähengen luomista (Archer \& Cameron 2013, 136; O'Leary $2015,538,545)$. Yhteistyösuhteiden rakentaminen muiden organisaatioiden kanssa vaatii aikaa (Archer \& Cameron 2013, 10, 212). Yhteistyön johtaminen on yhteydessä sosiaalisiin taitoihin. Park ja Faerman (2019) painottavat tunteita yhdessä sosiaalisten taitojen kanssa yhtenä johtajuuden kompetenssina. Myös johtajan kokemuksella on merkitystä. Tutkimuksen mukaan uudet johtajat läpikäyvät työssään kehitysvaiheita, joissa tunteiden, sosiaalisten taitojen kompe- tenssilla ja niiden kehittymisellä on suuri rooli. Organisaation tai verkoston arjella on vaikutuksensa asiaan.

\section{AINEISTO JA MENETELMÄT}

Tutkimuksen empiirinen osuus toteutettiin kolmannen sektorin verkostojohtajille suunnatulla kvalitatiivisella verkkokyselyllä. Vastaajat toimivat kolmannella sektorilla, ja heidän edustamansa järjestöt tekevät yhteistyötä monien eri sidosryhmien kanssa. Tässä tutkimuksessa käytämme oletuksellisesti kaikista kyselyyn vastanneista nimitystä "verkostojohtaja". Käytimme tätä termiä myös saatekirjeessä. Kysyttäessä mitä eri toimijoita vastaajien verkostoihin kuuluu, vastaajat ilmoittivat tekevänsä yhteistyötä eniten muiden järjestöjen tai yhdistysten ja kuntien kanssa. Tämän lisäksi yhteistyötahoja olivat yksityisen sektorin toimijat (yritykset) ja seurakunnat. Muita mainittuja tahoja olivat yliopistot, rahoittajat ja säätiöt. Kyselyssä vastaajat olivat voineet nimetä useamman yhteistyötahon.

Kyselyn tavoitteena oli kartoittaa sosiaali- ja terveysjärjestöjen (ml. säätiöt) ylimpien johtajien näkemyksiä osaamisvaatimuksista ja ominaisuuksista, joita verkostojohtajilta vaaditaan tulevaisuudessa. Verkkokyselyn etuna on, että sillä voidaan kerätä tietoa tehokkaasti ja sillä tavoitetaan kerralla suuri määrä vastaajia. Toisaalta varjopuolena on, että vastaajat voivat helposti poistaa viestin ja jättää vastaamatta kyselyyn. Toinen vaihtoehto olisi ollut kerätä aineisto haastattelujen avulla. Pidimme kuitenkin valittua tapaa kerätä tietoa tarkoituksenmukaisena tätä tutkimuskysymystä varten. Näin saimme tavoitettua laajan kohdejoukon, jonka haastattelu olisi vaatinut enemmän aikaa. Laadullisilla kysymyksillä halusimme kerätä vastaajien tulkintoja aiheesta.

Linkki kyselyyn lähetettiin kesällä 2017 yhteensä 214 sosiaali- ja terveysjärjestöjen johtajalle, joista kaksi jäi tavoittamatta. Tämä kattaa lähes kaikki kansalliset sosiaali- ja terveysalan kattojärjestöt. Kaiken kaikkiaan järjestöt kattavat noin 1,3 miljoona jäsentä (ks. SOSTE 2017). Kriteerinä oli, että järjestöt olivat valtakunnallisia. Järjestöjä ei valittu kyselyyn koon mukaan, eikä niiltä edellytetty paikallisyhdistystoimintaa. Kysely toteutettiin sekä suomeksi että ruotsiksi. Yhden muistutuskierroksen jälkeen vastauksia 
kertyi kaikkiaan 27, minkä johdosta vastausprosentiksi muodostui $13 \%$. Huolimatta alhaisesta vastausprosentista tutkimuksen aineisto oli sisällöllisesti monipuolinen ja sen avulla saatiin riittävästi vastauksia tutkimuksen kysymyksenasetteluun. Vastausmäärä oli kuitenkin tyydyttävä suhteessa laadullisen tutkimuksen tarkoitukseen. Aineiston pienuuden vuoksi tuloksia on vaikea yleistää. Alhaiseen vastausprosenttiin saattaa osaltaan vaikuttaa se, että kysely lähetettiin kesälomien kynnyksellä. Kysely perustuu avoimiin kysymyksiin, joihin vastaaminen saatettiin kokea aikaa vieväksi.

Vastaajien sukupuolijakauma oli seuraava: Suurin osa kyselyyn vastanneista oli naisia eli 16 vastaajaa (59\%), miehiä oli 6 (22\%) ja 5 henkilöä (19 \%) ei ilmoittanut sukupuoltaan. Vastaajien ikä vaihteli 25 - ja yli 56 -vuotiaiden välillä; yksikään vastaaja ei ollut alle 25 -vuotias. Johtamiskokemusta kyselyyn vastanneille oli kertynyt muutamasta vuodesta jopa yli kahteenkymmeneen vuoteen; kahdella vastaajista kokemus jäi alle vuoden mittaiseksi.

Verkkokysely sisälsi kysymyksiä yhteistyön johtamisen rooleista ja kompetensseista. Kysely oli jaoteltu kolmeen osaan, joista ensimmäisessä pyydettiin taustatietojen lisäksi osallistujia kuvaamaan lyhyesti, kuinka he näkevät oman roolinsa eri verkostoissa. Toisessa osassa kartoitettiin avoimilla kysymyksillä Agranoffin ja McGuiren (2001) luoman verkostojohtajan käyttäytymisen neljän eri kategorian (vaiheen) mukaan: yhteistyön käynnistäminen, yhteistyön rakentaminen, mobilisointi ja yhteistyön syventäminen, vastaajien käsityksiä kompetensseista näissä eri kategorioissa. Lomakkeessa kategoriat avattiin lyhyesti vastaajille. Kolmas osio sisälsi avoimia kysymyksiä yhteistyöhön perustuvan johtajuuden tulevaisuudesta ja haasteista.

Tutkimus perustui laadulliseen kyselyyn ja sisällönanalyysiin. Laadulliset tutkimukset voivat rakentua empiirisestä aineistosta, joka on suurelta osin tekstimuotoista tai sellaiseksi muutettua aineistoa. Sisällönanalyysin tarkoituksena on aineiston erittely, yhtäläisyyksien ja erojen löytäminen sekä tiivistäminen. Sisällönanalyysi on tekstinanalyysiä, eli tekstimuotoisten tai sellaisiksi muutettujen aineistojen tarkastelu. Sen päämääränä on muodostaa ilmiöstä tiivistetty kuvaus, joka kytkee tulokset laajempaan kontekstiin ja muihin tutkimuksiin. Laadullisen sisällönanalyysin aineisto puretaan osiin, sitten käsitteellistetään ja lopuksi järjestetään uudeksi kokonaisuudeksi. (Saaranen-Kauppinen \& Puusniekka 2006; Tuomi \& Sarajärvi 2002, 7475, 105, 109-116.) Tässä tutkimuksessa toteutimme teoriaohjaavaa sisällönanalyysiä, jossa aineisto jäsenneltiin Agranoffin ja McGuiren (2001) mallin tarjoamien kategorioiden mukaisesti, ja tutkittiin eroja ja yhtäläisyyksiä vastausten välillä. Tavoitteena oli löytää eri vaiheissa useimmiten mainitut kompetenssit, eli niin sanotut teemat, joille annettiin yhteinen nimittäjä. Esimerkiksi aineistossa mainitut kompetenssit kuten taito kuunnella, sosiaaliset taidot sekä neuvottelu- ja yhteistyötaidot nimesimme vuorovaikutus- ja verkostoitumistaidoiksi. Näistä kunkin edellä mainitun teoreettisen mallin kategorian alle muodostuneista kompetensseista johdettiin edelleen kolmannen sektorin verkostojohtajan uudet roolit. Tutkimuseettisenä periaatteena olemme noudattaneet tunnistettavuuden estämistä (ks. Kuula 2006, 201).

\section{KOLMANNEN SEKTORIN VERKOSTOJOHTAJIEN ROOLIT}

Kyselylomakkeen verkostojohtajien rooleja kartoittavassa kysymyksessä vastaajat kuvasivat ja nimesivät itse roolejaan moninaisesti $\mathrm{mm}$. seuraavilla sanoilla: koordinaattori, koollekutsuja, kollaboraattori (yhteistyön tekijä), verkoston ylläpitäjä, liideri (johtaja), asiantuntija, kehittäjä. Kyselyyn vastanneet saivat kuvailla rooliaan verkostoissa omin sanoin. Verkostojohtaja ei selvästi omannut vain yhtä roolia. Kuten eräät vastaajista osuvasti ilmaisivat:

\section{"Kaikkia mahdollisia rooleja, sillä verkostoja on paljon."}

"Beroende på vilket nätverk: sakkunnik, samordnare, leda, sammarbetspart är några roller jag kommer att tänka på."

Millaisiksi roolit muodostuivat, kun niitä tarkasteltiin verkostojohtajan käyttäytymisen neljässä eri kategoriassa: yhteistyön käynnistäminen, yhteistyön rakentaminen, mobilisointi ja yhteistyön syventäminen? Kyseinen tyypittely perustuu Agranoffin ja McGuiren (2001) tutkimukseen. Vastauksen saamiseksi kartoitimme verkosto- 
johtajan tärkeimpiä kompetensseja, joiden pohjalta muodostimme käsityksen siitä, mikä on verkostojohtajan rooli kussakin kategoriassa.

Yhteistyön käynnistämisen vaiheessa nousi selvästi kolme keskeistä kompetenssia. Ensimmäinen niistä oli selkeästi vuorovaikutus- ja verkostoitumistaidot; tässä vastaajat painottivat taitoa kuunnella, sosiaalisia taitoja sekä neuvottelu- ja yhteistyötaitoja. Toinen teema käsittää kompetenssit, joissa painottuu kyky asettaa tavoitteita ja visioida. Esille nousi kyvykkyys konkretisoida tavoitteita ja "myydä" ne verkostolle sekä löytää win-win asetelmia. Kolmanneksi teemaksi muodostui kyky motivoida, innostaa ja innovoida. Vastaajien mielestä oli tärkeää, että verkostojohtajalla olisi kyky saada ihmiset mukaan. McGuire ja Silvia $(2009,39)$ ovat todenneet aktivoinnin merkityksen olennaiseksi erityisesti verkostoyhteistyön käynnistämisessä, joten on siis hyvinkin ymmärrettävää, että vastaajat korostivat juuri kompetensseja, joilla yhteistyö saadaan alkamaan. Muutamien vastaajan sanoin verkostojohtajalla on oltava:

"...kyky maalata tavoitteita ja hyötyä mahdolliselle yhteistyölle, joka hyödyttää kaikkia osapuolia."

"Förmåga att engagera, att se helheter, bygga upp strategiprocesser med mål och delmål."

Yksittäisissä vastauksissa korostettiin niin ikään asiantuntemusta, kokonaisuuden hallintaa ja luottamusta sekä muita eettisiä kompetensseja (kuten erilaisuuden hyväksymistä), resilienssiä sekä suunnittelu- ja organisointitaitoja verkostojohtajan kompetensseina ja henkilökohtaisina ominaisuuksina verkostoyhteistyön käynnistämisen vaiheessa.

Yhteistyön rakentamisen vaiheessa sovitaan verkoston säännöistä sekä käydään läpi verkoston toiminnan tavoitteet ja odotukset. Lisäksi on tärkeää huolehtia osapuolten sitoutumisesta. (Agranoff \& McGuire 2001, 299; McGuire 2006, 37; McGuire \& Silvia 2009, 39.) Kolmannen sektorin verkostojohtajilta kysyttiin näkemystä, miten verkoston sisällä voidaan luoda yhteisyyttä ja miten johtaja voi tähän vaikuttaa. Vastaajat korostivat ensinnäkin verkoston johtajan kykyä kommunikoida avoimesti. Useissa vastauksis- sa tuli esille paitsi vuorovaikutuksen avoimuus niin kaikki verkoston osapuolet kattava kommunikaatio ja kuulluksi tuleminen: "Jokaisen pitää saada äänensä kuuluviin", totesi yksi vastaaja. Tähän liittyen johtajalta edellytetään keskustelufoorumien luomista, ja jatkuva vuorovaikutus on tänä päivänä yhä helpompi toteuttaa erilaisten digitaalisten keinojen avulla. Vastaajat toivatkin esille sosiaalisen median ja virtuaalikokoukset.

Yhteistyön rakentamisen vaiheessa toiseksi tärkeimmäksi teemaksi muodostui osallisuus ja verkostojohtajan kyky sitouttaa osapuolia yhteistyöhön. Kuten eräs vastaaja totesi:

"Osallisuuden varmistaminen on ehdoton lähtökohta. Kaikkien verkostokumppaneiden tulee tuntea olevansa osa verkostoa."

Verkostojohtajaa kohtaan muodostui tässä isoja odotuksia:

"Ledaren är förebilden för engagemang och skall på gruppens villkor sammanföra den till en fungerande helhet. Krävs gruppkännedom, förmåga att se helheter och styrkor samt hur gruppen bäst kan fungera tillsammans."

Myös sitoutumisen merkitys korostui. Kuten eräs vastaaja totesi: "Ihmiset eivät sitoudu 'annettuun agendaan' elleivät voi itse vaikuttaa verkoston tavoitteisiin, jolloin myös ideointiin on oltava aikaa." Kolmannessa teemassa korostui yhteisistä pelisäännöistä sopiminen. Se liittyy osapuolten odotusten ja tavoitteiden läpikäymiseen, yhteisten tavoitteiden asettamiseen sekä yhteisten päämäärien kirkastamiseen:

"Pitää jämäkästi prosessoida se mitä ollaan tekemässä: kuka tekee mitäkin ja millä aikataululla ja budjetilla. Mikä on kuluvastuu ja miten tulot jaetaan. Kun on jämäkkä toimintatapa, myös yhteinen tahtotila ja verkostoituminen toimii."

Vastaajia pyydettiin myös kertomaan, miten pitää yllä hyvää vuorovaikutusta sekä edistää avoimuutta verkoston eri toimijoiden välillä. Vastauksissa tuli esille jatkuva vuorovaikutus, keskusteleva työskentely ja kaikkien tasapuoli- 
nen kuuleminen sekä erilaisten viestintäkanavien hyödyntäminen. Tämän voi tiivistää erään vastaajan sanoin:

\section{"Viestimällä niin hemmetisti"}

Toiseksi useimmiten vastaajat mainitsivat kumppanuuden, luottamuksen, toisten kunnioittamisen ja valmiuden oppia toisiltaan. Tätä kuvasi seuraava kommentti:

"Lähtökohtana kumppanuuden edellytykset: tasavertaisuus, työskentelymuotojen suunnittelu, sitoutumisen tukeminen, arvostuksen rakentaminen kaikkien osallistujien kesken."

Mobilisoinnin vaiheessa verkoston säännöt on sovittu sekä toiminnan tavoitteet ja odotukset on käsitelty ja osapuolia on sitoutettu yhteistyöhön. Verkostojohtajan tehtävänä on motivoida toimijoita eri tavoin mobilisoinnin vaiheessa. On myös tärkeää, että verkostojohtaja saa omalta taustaorganisaatioltaan tarvittavaa tukea. (Agranoff \& McGuire 2001, 300; McGuire \& Silvia 2009, 39-40.) Miten verkostojohtaja voi motivoida toimijoita? Verkostojohtajan tärkeitä kompetensseja olivat johtajan kyky kirkastaa tavoitteita sekä kyky pitää aktiivisesti yhteyttä, kannustaa ja kiittää osapuolia. Vastaajat liittivät tavoitteiden kirkastamiseen myös kannustavia elementtejä. He kirjoittivat "lupaavan tulevaisuuden maalaamisesta", "etunäkymän avoimena pitämisestä" ja jokaisen osapuolen hyötyjen esillä pitämisestä." Vastauksissa korostuivat yhteisten tavoitteiden ja tehtävien kautta motivointi, sen sijaan ulkoisia motivointikeinoja, kuten palkkioita ei juurikaan tuotu esille. Erään vastaajan mukaan olisi tärkeää huomata, ettei kaikkia voi motivoida samalla tavalla.

Agranoff $(2005,34)$ painottaa verkostojohtajan saamaa taustatukea omasta "kotiorganisaatiostaan." Tuen merkitys tuli esille vastaajien kommenteissa. Sitä pidettiin yleisesti ratkaisevan tärkeänä:

"Utan organisationens stöd, fungerar inte arbetet."

Yhteistyön syventämisen vaiheessa verkostojohtajan haasteena on luoda suotuisa ilmapiiri yhteistyölle ja tukea menestyksellistä yhdessä työs- kentelyä sekä poistaa yhteistyön esteitä. Siihen liittyy luottamuksen ylläpitäminen osapuolten kesken. (McGuire 2006, 37; McGuire \& Silvia 2009,40 .) Verkostojohtajilta kysyttiin, millaisia kompetensseja verkostojohtaja tarvitsee, jotta luottamus verkostossa vahvistuu. Vastausten perusteella nimesimme ne eettisiksi kompetensseiksi. Tarkemmin kuvattuna ne tarkoittavat toisten arvostamista, eettisiä toimintatapoja, diplomaattisuutta ja kykyä sovitella. Toisten arvostamista pidettiin kaikkein tärkeimpänä elementtinä. Vastaajien mukaan siihen liittyy myös eri osapuolten huomioiminen ja kunnioittaminen ja myönteisen palautteen antaminen. Eettisillä toimintatavoilla tarkoitettiin erityisesti luottamusta herättävää tapaa toimia, tasapuolisuutta sekä erään vastaajan sanoin "tasa-arvoisen vuorovaikutuksen kehittämisen osaamista". Verkostoyhteistyössä tapahtuu väistämättä erilaisia yhteentörmäyksiä. Siksi verkostojohtajan olisi osattava toimia diplomaattisesti; käsiteltävä ristiriitoja ja erilaisia näkemyksiä rakentavassa hengessä ja rohkeasti. Seuraava lainaus tiivistää verkostojohtajan roolin:

"Kuuntelee ja kokoaa, etsii esitetystä asiasta sen yhteisen sävelen."

"Johtajan tehtävä on auttaa ihmisiä verkottumaan keskenään. Johtaja rohkaisee ihmisiä tekemään yhteistyötä ja osoittaa sen hedelmällisyyden. Johtaja muistuttaa verkoston jokaista osaa yhteisestä isosta kuvasta."

Vastaajat korostivat myös vuorovaikutustaitojen, asiantuntemuksen sekä jämäkkyyden merkitystä. Archer ja Cameron $(2013,138)$ esittävät, että verkostojohtajan tehtävänä on ratkaista rakentavasti esille tulevat konfliktit. Se vaatii heidän mukaansa kykyä auttaa ihmisiä ymmärtämään toistensa motiiveja ja näkökulmia. Kyselyyn vastanneet verkostojohtajat korostivat, että tapa puuttua verkostossa tapahtuviin ristiriitoihin on ennen kaikkea avoin keskustelu. Vastauksissa painottuivat myös Archerin ja Cameronin (2013) esille nostama rakentava ja kannustava tapa puuttua. Seuraava sitaatti tiivistää vastaajien näkemykset osuvasti:

"Genom att uppmana till respekt och dialog" 
Taulukko 1. Verkostojohtajan roolit neljässä käyttäytymisen kategoriassa.

\begin{tabular}{lll}
\hline $\begin{array}{l}\text { Käyttäytymisen } \\
\text { kategoria }\end{array}$ & Kompetenssit & Johtajan rooli \\
\hline $\begin{array}{l}\text { Yhteistyön } \\
\text { käynnistäminen }\end{array}$ & $\begin{array}{l}\text { Kuorovaikutus- ja verkostoitumistaidot } \\
\text { Kyky mottivoida, inspiroida ja innovoida }\end{array}$ & Visionäärinen motivaattori \\
\hline Yhteistyön & Kyky kommunikoida avoimesti & Yhteisöllisyyden rakentaja \\
rakentaminen & Kyky sitouttaa muita & \\
& Kyky selventää yhteinen missio & \\
\hline Mobilisointi & Kyky selventää tavoitteet & Strateginen stimulaattori \\
& Kyky vahvistaa avointa tiedonvälitystä ja & \\
& osoittaa kiitollisuutta & Reilu välittäjä \\
\hline Yhteistyön & Eettiset kompetenssit & \\
syventäminen & Kyktiritojen tunnustaminen & \\
& Asiantuntemus ja jämäkkyss & \\
\hline
\end{tabular}

Vastaajat korostivat sen tärkeyttä, että konfliktit tunnistettaisiin välittömästi niiden ilmaannuttua ja sovittaisiin pelisäännöistä jo etukäteen. Tilanteiden ratkaisussa oli tärkeää avoin, kasvokkainen keskustelu.

Yhteenvetona voidaan todeta, että vastaajat korostivat verkostojohtajan käyttäytymisen neljässä eri kategoriassa (yhteistyön käynnistäminen, yhteistyön rakentaminen, mobilisointi ja yhteistyön syventäminen) (Agranoff \& McGuire 2001) osin erilaisia kompetensseja. Näistä kompetensseista voidaan johtaa ne roolit, joita verkostojohtaja tarvitsee eri vaiheissa. Yhteistyön käynnistämisen vaiheessa kompetenssit, kuten vuorovaikutus, innovoiminen ja visioiden luomisen taito, asettavat verkostojohtajan rooliksi visionäärisen motivaattorin. Yhteistyön rakentamisen vaiheessa verkostojohtajan rooli voidaan tulkita yhteisöllisyyden rakentajaksi, sillä tässä on oleellista, että johtaja kykenee sitouttamaan muita ja omistautumaan avoimeen vuorovaikutukseen ja mission luomiseen. Strateginen stimulaattori selkeyttää tavoitteet ja antaa kiitosta verkoston toimijoille. Viimeiseksi tarvitaan eettistä osaamista ja diplomaattisuutta, jotta yhteistyö voi syventyä; tällöin johtajan rooliksi määrittyy reilu välittäjä. Tiivistettynä roolit näkyvät eri vaiheissa taulukossa 1 .

Kuten aiemmin todettu, Getha-Taylorin (2008) kompetenssimallin mukaan verkostojoh- taminen perustuu interpersonaaliseen ymmärtämiseen, yhteistyöhön ja moninaisuutta sovittavaan johtajuuteen. Kyselyyn vastanneet arvostivat kompetenssimallin kaltaisesti muiden motivointia sekä näkemysten ja tarpeiden huomiointia yhteistyön käynnistämisen vaiheessa. Tämä edellyttää interpersonaalista ymmärtämistä ja kyseisen kompetenssin kehittämistä. Yhteistyön rakentamisessa Getha-Taylorin mallista korostuvat yhteistyön ja johtajuuden kompetenssit. Verkostoon osallistuvien mukaan ottaminen ei perustu pelkästään motivointiin ja muiden tarpeiden huomioimiseen, sillä moninaisuutta sovitetaan yhteisen mission selventämisellä (näkölinjan luominen). Tavoitteiden selventäminen ja avoin tiedonvälitys ovat vuorostaan yhteydessä jaettuun ymmärrykseen ja kielenkäyttöön. Yhteistyön syventämisessä eettinen kompetenssi sisältää ristiriitojen sovittamista, joka on yhteydessä Getha-Taylorin käsitykseen kollaboraatiosta: konfliktit nähdään myös mahdollisuutena eikä uhkana, ja ongelmanratkaisussa huomioidaan kaikkien hyöty. Kyselyyn vastanneet yhdistivät nämä kompetenssit yhteistyön syventämiseen ja diplomaattisuuteen.

Yhteistyön eri vaiheissa ja tehtävissä tarvitaan erilaisia rooleja. Verkostojohtajalta vaaditaan joustavuutta ja kykyä mukauttaa käyttäytymisensä verkoston vaatimuksiin ja jatkuvasti muuttuvien yhteiskunnallisten tilanteiden tuomiin 
odotuksiin ja muutoksiin. Tulevaisuudessa verkostojohtajan on oltava vuorovaikutuksessaan avoin, yhteistyökykyinen ja joustava. Kuten vastaajat toivat esiin, muuttuva toimintaympäristö edellyttää uudenlaista johtajuutta.

"Vaatii enemmän yhteistyötä, tavoitehakuisuutta ja kykyä ratkaista asioita uudenlaisilla toimintamalleilla ennakkoluulottomasti yhdistämällä erilaisia osaamisia."

\section{JOHTOPÄÄTÖKSET}

Tämän tutkimuksen tarkoituksena oli kartoittaa verkostojohtajan kompetensseja ja rooleja kolmannen sektorin verkostotoimijoiden näkökulmasta. Analyysin perusteella verkostojohtajalla on neljä uutta roolia johtaessaan sektoreiden välistä yhteistyötä. Saatuja vastauksia voidaan pitää informatiivisina ja hyödyllisinä. Vastaajamme edustivat kolmannen sektorin organisaatioita Suomessa ja he olivat mukana lukuisissa yhteistyöasetelmissa. Sektoreiden välinen yhteistyö on usein välttämätöntä monimutkaisten sosiaalisten ja yhteiskunnallisten ongelmien ratkaisemiseksi. On oletettavaa, että kolmannen sektorin merkitys hyvinvointipalveluiden tuottajana tulee jatkossa entisestään kasvamaan. Poliittinen päätöksenteko vaikuttaa sosiaali- ja terveysalan järjestöjen toimintaan: sitä kautta se tuo verkostoyhteistyöhön Puustisen (2017) esiin tuomaa ennalta-arvaamattomuutta. Muuttuva toimintaympäristö edellyttää verkostojohtajalta uudenlaisia rooleja. Kyselyyn vastanneet verkostojohtajat identifioivat itselleen monia rooleja, riippuen verkostosta ja sen toiminnan vaiheista. On ilmeistä, että verkostotoiminnan eri vaiheissa johtajan toiminnalta edellytetään erilaisia kompetensseja ja rooleja.

Tutkimusten tulosten mukaan ensinnäkin aktivointivaiheessa on keskeistä tunnistaa ja sitouttaa oikeat ihmiset ja resurssit verkostoyhteistyöhön yhteisten tavoitteiden saavuttamiseksi. Johtajan roolina on toimia visionäärisenä motivaattorina. Johtajalta vaadittavat kompetenssit ovat vuorovaikutus- ja verkostoitumistaidot sekä kyky asettaa tavoitteita ja motivoida verkoston osapuolet toimimaan niiden suuntaisesti.

Toiseksi, yhteistyön rakentamisen vaiheessa johtajan on otettava yhteisöllisyyden rakentajan rooli. Voidaanko kenties olettaa, että juuri yh- teisöllisyyden rakentaminen painottuu kolmannella sektorilla enemmän kuin kenties julkisella sektorilla, sillä kolmas sektori nojaa vahvasti vapaaehtoistyöhön? Verkostojohtajat pitivät silloin tärkeänä kykyä kommunikoida avoimesti, sitouttaa muita ja kirkastaa yhteistä päämäärää. Kolmas vaihe on nimetty mobilisointivaiheeksi. Tällöin johtajan rooliksi muodostuu strateginen stimulaattori, jolloin häneltä edellytetään osin samanlaisia kompetensseja. Niissä korostuvat yhteisten tavoitteiden selventäminen, avoimen vuorovaikutuksen mahdollistaminen ja erityisesti tuen ja kiitoksen antaminen eri osapuolille. Neljännessä vaiheessa eettiset kompetenssit, diplomaattisuus ja jämäkkyys ovat tarpeen vahvistamaan luottamusta ja syventämään yhteistyötä verkostotoimijoiden kesken. Verkostojohtajan roolin nimesimme reiluksi välittäjäksi.

Johtopäätöksenämme toteamme, että ihmisten johtamisen taidot, kyky inspiroida ja motivoida ovat verkostojohtajalta vaadittavien kompetenssien ydintä. Tähän vaikuttanee osaltaan se, että kolmannen sektorin toiminta rakentuu pitkälti vapaaehtoistyön varaan. Kolmannen sektorin keskeisinä resursseina toimivat ihmiset itse. Tärkein tapa motivoida heitä on tehdä heidän panoksensa näkyväksi ja osoittaa sille arvostusta. Luottamuksen merkitys on tullut vahvasti esille, kuten myös se, että verkostossa toiminnan tavoitteet ja odotukset ovat usein ristiriitaisia ja siksi yhteisen hyödyn hakeminen ja korostaminen ovat tärkeitä asioita. Kukaan kyselyyn vastanneista kolmannen sektorin johtajista ei maininnut hierarkkisuutta verkostoyhteistyössä. Päinvastoin, he korostivat jaettua valtaa. Jaetun johtamisen ajattelu- ja toimintamalli mahdollisesti tulee vielä korostumaan tulevaisuuden verkostoissa, kuten myös McGuire ja Agranoff (2014) antavat ymmärtää. Näin on myös Getha-Taylorin (2008) kompetenssimallin laita. Hierarkkiset rakenteet eivät välttämättä ole optimaalisia sen tunnistamisessa, että verkostossa voi olla läsnä hyvin erilaisia arvolähtökohtia ja ristiriitoja. Tämä edellyttää mahdollisten konfliktien olemassaolon tunnistamista, ei huomioimatta jättämistä. Myös yhteisen mission löytäminen verkostoissa on jaetun johtamisen periaatteiden mukaista.

Tutkimuksemme tavoitteena oli tuottaa laadullinen analyysi verkostojohtajien kompetensseista heidän itsensä tulkitsemana. Tämäkään 
joukko ei ole yhtenäinen, vaikka heidän vastaustensa sisältö tavoilla, joilla he kuvaavat verkostojohtajalta vaadittavia asioita, on verraten yhdenmukainen ja ristiriidaton. Aineiston pienuuden vuoksi tulokset eivät ole yleistettävissä, mutta ne lisäävät ymmärrystä yhden johtajaryhmän, nimittäin Suomessa kolmannella sektorilla toimivien verkostojohtajien rooleista ja kompetensseista. Aineistoa olisi voinut täydentää esimerkiksi haastatteluilla, mikä antaakin mahdollisuuksia jatkotutkimukseen. Haastattelut syventäisivät johtajien näkemyksiä sidosryhmien

\section{LÄHTEET}

Agranoff, Robert \& McGuire, Michael (2001). Big questions in public networks management research. Journal of Public Administration Research and Theory, 11(3), 295-326.

Agranoff, Robert (2005). Managing collaborative performance: Changing the boundaries of the state? Public Performance \& Management Review, 29(1), 18-45.

Agranoff, Robert (2006). Inside collaborative networks: Ten lessons for public managers. Public Administration Review, 66(1), 56-65.

Archer, David \& Cameron, Alex (2013). Collaborative leadership: Building relationships, handling conflict, sharing control. New York: Routledge.

Ansell, Chris \& Gash, Alison (2008). Collaborative governance in theory and practice. Journal of Public Administration Research and Theory, 18(4), 543-571.

Ansell, Chris \& Gash, Alison (2012). Stewards, mediators, and catalysts: Toward a model of collaborative leadership. The Innovation Journal: The Public Sector Innovation Journal, 17(1), 1-21.

Bevir, Mark (2013). A Theory of Governance. London: University of California Press.

Bryson, John M., Crosby, Barbara C. \& Stone, Melissa M. (2006). The design and implementation of cross-sector collaborations: Propositions from the literature. Public Administration Review, 66(1), 44-55.

Bryson, John M., Crosby, Barbara C. \& Stone, Melissa M. (2015). Designing and implementing cross-sector collaborations: Needed and challenging. Public Administration Review, 75(5), 647-663.

Crosby, Barbara C \& Bryson, John M. (2010). Integrative leadership and the creation and maintenance of cross-sector collaborations. Leadership Quarterly, 21(2), 211-230. merkityksestä. Muutokset sosiaali- ja terveydenhuollon kentässä ovat edelleen meneillään. Tuloksia voidaan hyödyntää sekä järjestösektorin koulutustoiminnassa ja laajemmin kansalaisjärjestökentällä: etenkin vuorovaikutustaidot ja luottamus ovat asioita, joiden rakentamiseen on hyvä kiinnittää jatkossa huomiota yhä enemmän. Sen vuoksi aihe on ajankohtainen tulevaisuudessakin. Verkostojohtajan kompetenssit muuttuvassa kolmannen sektorin toimintakentässä ansaitsevat tulla tutkituiksi syvemmin.

Farazmand, Ali (2002). Administrative ethics and professional competence: Accountability and performance under globalization. International Review of Administrative Sciences, 68, 127-143.

Follett, Mary P. (1924). Creative Experience. New York: Longmans, Green and co.

Foster-Fishman, Pennie G., Berkowitz, Shelby L. Lounsbury, David W., Jacobson, Stephanie \& Allen, Nicole A. (2001). Building Collaborative Capacity in Community Coalitions: A Review and Integrative Framework. American Journal of Community Psychology, 29(2), 241-261.

Getha-Taylor, Heather (2008). Identifying collaborative competencies. Review of Public Personnel Administration, 28(2), 103-119.

Getha-Taylor, Heather \& Morse, Ricardo S. (2013). Collaborative leadership development for local government officials: Exploring competencies and program impact. Public Administration Quarterly, 37(1), 72-103.

HE (15/2017). Hallituksen esitys eduskunnalle maakuntien perustamista ja sosiaali- ja terveydenhuollon järjestämisen uudistusta koskevaksi lainsäädännöksi sekä Euroopan paikallisen itsehallinnon peruskirjan 12 ja 13 artiklan mukaisen ilmoituksen antamiseksi.

Heikka, Helena (2008). Sosiaali- ja terveysjohtajan työn sisältö ja kompetenssit. Acta Universitatis Ouluensis D 968. Oulu: Oulun yliopisto.

Huxham, Chris \& Vangen, Siv (2000). Leadership in the shaping and implementation of collaboration. How things happen in a (not quite) joined-up world. Academy of Management Journal, 43(6), 1159-1175.

Huxham, Chris \& Vangen, Siv (2008). Managing to collaborate. The theory and practice of collaborative advantage. London: Routledge.

Imperial, Mark T., Ospina, Sonia, Johnston, Erik, O'Leary, Rosemary, Thomsen, Jennifer, 
Williams, Peter \& Johnson, Shawn (2016). Understanding leadership in a world of shared problems: advancing network governance in large landscape conservation. Front Ecol Environ 14(3), 126-134.

Jäppinen, Aini-Kristiina (2012). Onnistu yhdessä! Työyhteisön kehittämisen 10 avainta. Jyväskylä: PS-Kustannus.

Klijn, Erik-Hans (2008). Governance and governance networks in Europe: An assessment of ten years of research on the theme. Public Management Review, 10(4), 505-525.

Kuula, Arja (2006). Tutkimusetiikka: Aineistojen hankinta, käyttö ja säilytys. Tampere: Vastapaino.

Lambright, Kristina, Mischen, Pamela \& Laramee, Graig (2010). Building trust in public and nonprofit Networks: Personal, Dyadic, and ThirdParty Influences. The American Review of Public Administration, 40(1), 64-82.

Macaulay, Michael \& Lawton, Alan (2006). From virtue to competence: Changing the principles of public service. Public Administration Review, 66(5), 702-710.

McGuire, Michael (2002). Managing networks: proportions on what managers do and why they do It. Public Administration Review, 65(5), 599-609.

McGuire, Michael (2006). Collaborative public management. Assessing what we know and how we know it. Public Administration Review, 66(1), 33-43.

McGuire, Michael \& Silvia, Chris (2009). Does leadership in networks matter? Public Performance and Management Review, 33(1), 34-62.

McGuire, Michael \& Agranoff, Robert (2014). Network Management Behaviors: Closing the Theoretical Gap. Teoksessa Keast, Roby Mandell, Myrna \& Agranoff, Robert (toim.): Network Theory in the Public Sector: Building New Theoretical Frameworks (s. 137-156). New York: Routledge.

McGuire, Michael \& Silvia, Chris (2015). Managing effective collaborations. Teoksessa Perry, James L. \& Christensen, Robert K. (toim.): Handbook of Public Administration (s. 293-311). John Wiley \& Sons. E-kirja.

Morse, Ricardo S. (2008). Developing Public Leaders in an Age of Collaborative Governance. Teoksessa Ricardo S. Morse \& Terry F. Buss (toim.) Innovations in Public Leadership Development, (s. 79-100). Armonk, N.Y: M.E. Sharpe.

Möttönen, Sakari (2005). Kunta ja kolmas sektori. Yhteistyön uudet muodot. Jyväskylä: PSkustannus.
Niiranen, Vuokko (2016). Uudistuvat verkostot ja yhteistyörakenteet johtamisessa. Teoksessa Syväjärvi, Antti \& Pietiläinen, Ville (toim.): Inhimillinen ja tehokas sosiaali- ja terveysjohtaminen (s. 297-318). Tampere: Tampere University Press.

Niiranen, Vuokko (2017). Moniammatillisten verkostojen johtaminen. Teoksessa Rissanen, Sari \& Lammintakanen, Johanna (toim.): Sosiaalija terveysjohtaminen (s. 129-146). 3. uudistettu painos. Helsinki: Sanoma Pro oy.

O’Brien, Julia D., Littlefield, Jennifer N. \& Goddard-Truitt, Victoria (2013). A matter of leadership: Connecting a grantmaker's investments in collaborative leadership development to community results. The Foundation Review, $5(1), 26-42$.

O'Leary, Rosemary, Choi, Yujin \& Gerald, Catherine M. (2012). The skill set of the successful collaborator. Public Administration Review, 72(1), 70-83.

O'Leary, Rosemary (2015). Becoming and being an effective collaborator. Teoksessa James L. Perry \& Robert K. Christensen (toim.) Handbook of Public Administration (s. 528-545). John Wiley \& Sons. E-book.

Osula, Bramwell \& Ng, Eddies C.W. (2014). Toward a collaborative transformative model of nonprofit leadership: Some conceptual building blocks. Administrative Sciences, 4(2), 87-104.

Park, Hyun Hee \& Faerman, Sue (2019). Becoming a manager: Learning the importance of emotional and social competence in managerial transitions. American Review of Public Administration, 49(1), 98-115.

Parkkinen, Jonne, Haveri, Arto \& Airaksinen, Jenni (2017). Yhdistävä johtajuus. Tutkimus kuntajohtajien osaamistarpeiden muutoksista. ACTA 268. Suomen Kuntaliitto.

Puustinen, Alisa (2017). Voiko verkostoa johtaa? Tapaustutkimus sosiaali- ja terveydenhuollon yhteistoiminta-alueen hallinnan yhteenkietoutuneesta luonteesta. Itä-Suomen yliopiston julkaisuja. Dissertations in Social Sciences and Business Studies, 149. Kuopio: Itä-Suomen yliopisto.

Saaranen-Kauppinen, Anita \& Puusniekka, Anna (2006). KvaliMOTV: Menetelmäopetuksen tietovaranto [verkkojulkaisu]. Tampere: Yhteiskuntatieteellinen tietoarkisto [ylläpitäjä ja tuottaja]. <http://www.fsd.uta.fi/menetelmäopetus/>. (Viitattu 29.1.2019.)

Silvia, Chris (2011). Collaborative governance concepts for successful network leadership. State and Local Government Review, 43(1), 66-71. 
Simo, Gloria \& Bies, Angela L. (2007). The role of nonprofits in disaster response: An Expanded model of cross-sector collaboration. Public Administration Review, 67(1), 125-142.

SOSTE (2017). Suomen Sosiaali- ja terveys ry. Haettu sivulta http://www.soste.fi, 5.5.2017.
Tiihonen, Seppo (2008). From Governing to Governance: A Process of Change. Tampere: Tampere University Press.

Tuomi, Jouni \& Sarajärvi, Anneli (2002). Laadullinen tutkimus ja sisällönanalyysi. Helsinki: Tammi. 